\title{
THE INCIDENCE OF INFECTION AMONG CONTACTS OF POLIOMYELITIS CASES ${ }^{1}$
}

\author{
By DOROTHY M. HORSTMANN, ROBERT W. McCOLLUM, AND ANNE D. MASCOLA \\ (From the Section of Preventive Medicine, Yale University School of Medicine, \\ New Haven, Conn.)
}

(Submitted for publication June 10, 1955; accepted June 29, 1955)

One of the epidemiological features which puzzled early students of poliomyelitis was the apparently erratic spread of the disease with rarely more than one case in a family. Subsequently, it became apparent that unlike measles among the common virus diseases, the majority of infections with poliomyelitis virus were either mild or inapparent and, therefore, went undetected. A number of epidemiological survey studies carried out during the past two decades indicated that actually a high infection rate was common among family contacts of poliomyelitis cases even though only one individual in the family became sick. Until recently, however, the laboratory methods available for studying the problem were largely limited to the isolation of virus by monkey inoculation, and the exact rates or degree of spread of this infection through families remained unknown. With the introduction of tissue culture methods into poliomyelitis research, it has been possible to carry out more extensive virological studies, and to relate virus isolation-or its absence-to the immune or antibody status of the individuals tested. The present study is concerned with poliomyelitis infection rates among close contacts of cases and indicates actually how high they may be. Tissue culture methods, which have been brought to bear on the problem, have been responsible for these results.

\section{MATERIALS AND METHODS}

Contacts of cases occurring in an epidemic in rural Ohio involving Wayne and Medina counties during the summer of 1952 formed the subjects for this study. The outbreak was a sharp one beginning in June and reaching a peak by the end of July. Overall attack rates in the two counties were 193 and 280 per 100,000, respectively, with mortality rates of 16 and 8.2 per 100,000 (1). Many of the cases occurred in small towns with a population of several hundred to a thousand. A relatively large number of families with multiple cases was noted.

1 Aided by a grant from the National Foundation for Infantile Paralysis, Inc.
Collection and preservation of specimens. ${ }^{2}$ Our study was carried out between $20 \mathrm{June}$ and $11 \mathrm{July}, 1952$. As soon as possible after a case of poliomyelitis arising in the study area was hospitalized or reported to the health officer, a visit was made to the family and neighborhood contacts by one of us. Inquiries were made as to whether individuals in these groups had had any illness within the previous few days or weeks; and whether any of the children had symptoms at the time of the visit. If the latter were found, the children were examined and their temperatures recorded.

A number of children who had not been ill enough to have been seen by a physician, nevertheless gave histories of recent short mild illnesses, with sore throat, headache, fever, and gastrointestinal symptoms, in various combinations, without evidence of central nervous system disease. These were considered by us to be possible or probable examples of abortive poliomyelitis. Among the rest, a few had vague symptoms which were not well enough defined to be classified as abortive poliomyelitis, and many were completely asymptomatic.

Contacts were classified either as: household, if they were part of the same family unit as the index case; or daily, if they had regular daily contact with the case, such as playmates, close neighbors, etc. The study was focussed on 91 contacts of index cases occurring in 28 families. Of the contacts studied, 54 were regarded as household, and 37 as daily. An effort was made to obtain throat swabs, rectal swabs, and blood specimens from as many of these individuals as possible, particularly those under 15 years of age. The specimens, collected from 91 persons, are listed in Table I by age groups. In addition, stool specimens, collected in the acute phase of the disease, were obtained from nine hospitalized cases, four of whom were index cases of the contacts studied. Throat and rectal swabs were placed in nitrocellulose tubes containing $1 \mathrm{ml}$. of 50 per cent

${ }^{2}$ We are grateful for the generous help and coöperation of Dr. E. E. Kleinschmidt, then Health Commissioner of the Wayne and Medina Counties General Health District; to Dr. Frederick Wentworth, Chief of the Communicable Disease Division, Ohio State Department of Health, and their staffs; to Dr. James Kramer, Chief of Staff, Childrens Hospital, Akron, Ohio; and to Mr. Edward Tulley, chairman of the Summit County, Ohio, Chapter of the National Foundation for Infantile Paralysis. We are also indebted to Dr. Claude Reed, Miss Ilah Kauffman, and Mrs. Berttina Orsborne, for assistance in the collection of specimens. 
TABLE I

Types of specimens collected from 91 contacts of poliomyelitis cases

\begin{tabular}{cccc}
\hline & \multicolumn{3}{c}{ Numbers and types of specimens } \\
\cline { 2 - 4 } Age & T, R, B1* & T, Bl & R, Bl \\
\hline $0-4$ & 25 & 4 & 1 \\
$5-9$ & 16 & 10 & 1 \\
$10-14$ & 16 & 10 & \\
$15-19$ & 3 & 5 & \\
$20+$ & & 29 & 2 \\
\hline Total & 60 & & \\
\hline
\end{tabular}

$* \mathrm{~T}=$ throat swab; $\mathrm{R}=$ rectal swab; $\mathrm{Bl}=$ blood.

glycerine and frozen on dry ice soon after collection. Stool specimens were frozen directly. Whole blood was collected in $20 \mathrm{ml}$. amounts in vacuum tubes ${ }^{3}$ containing potassium oxalate as anticoagulant. The tubes of blood were centrifuged at $3000 \mathrm{rpm}$ before freezing, thus layering the plasma, white cells and red cells. All specimens were transported to New Haven in the frozen state, and kept frozen at $-20^{\circ}$ until tested.

Throat and rectal swabs were prepared for inoculation by removing the cotton tips and squeezing them out thoroughly in $1 \mathrm{ml}$. of sterile saline. The eluate was spun at $3,000 \mathrm{rpm}$ for $5 \mathrm{~min}$. before being inoculated in $0.1 \mathrm{ml}$. amounts into tissue culture tubes. At first, monkey testicular roller tubes prepared by the plasma clot method (2) were used, 2 per specimen; all tubes showing any cellular degeneration were passed, while those in which no cytopathogenic effect was observed were discarded after 12 days' observation. Later, when it became apparent that monkey kidney tissue is more sensitive to small amounts of virus, all specimens which had been negative in testicular tubes were retested, using 4 to 6 kidney tubes per specimen, and following the same procedures for harvesting and passing as previously employed (3). By this method a number of positive results were obtained with specimens which had been negative in testicular tubes. Finally, the remaining negatives were retested by the suspended cell technique (4), using monkey kidney tissue and harvesting and passing to kidney epithelial outgrowth tubes at 5, 10, and 15 days after inoculation. No additional virus isolations resulted from this procedure.

Stools. Specimens were prepared for inoculation as described by Riordan, Ledinko, and Melnick (5). Twenty per cent suspensions were made with sterile distilled water, and spun at $3,000 \mathrm{rpm}$ for 10 minutes. The supernatant fluid was then spun at $18,000 \mathrm{rpm}$ for one-half hour in a refrigerated centrifuge. Following this, $3 \mathrm{ml}$. of supernatant was mixed thoroughly with ether and held at $4^{\circ} \mathrm{C}$. overnight. After a further low speed centrifugation and removal of ether, $0.1 \mathrm{ml}$. was used as inoculum for each tissue culture tube. Monkey testicular tissue roller tubes were employed; they were followed in the same manner as those inoculated with throat and rectal swabs.

3 Bekton-Dickinson "Vacutainer" tubes.
Typing of strains isolated. Virus strains isolated from throat swabs, rectal swabs, and stools, were typed according to methods previously reported from this laboratory (5). Viruses were tested against a 1:5 dilution of hyperimmune monkey sera, prepared by immunization with Brunhilde (Type I), Y-SK (Type II), and Leon (Type III) strains. Complete inhibition of virus multiplication by one type only was taken to mean specific neutralization.

The blood specimens were all tested for the presence of poliomyelitis virus as described elsewhere (6).

Antibody tests. The presence of neutralizing antibodies against the three types of poliomyelitis virus in the blood specimens was determined in tissue culture neutralization tests (2), using monkey kidney tissue tubes (3). A single determination was made with plasma in a 1:5 dilution against 100 tissue culture doses of poliomyelitis virus. Strains used in the neutralization tests were tissue culture adapted Brunhilde for Type I; Y-SK for Type II; and Leon for Type III.

\section{RESULTS}

\section{Isolation of virus from contacts and cases}

Poliomyelitis virus was isolated from various sources from 28 of the 91 individuals designated as contacts, and from all nine of the hospitalized paralytic and nonparalytic cases tested. All the strains of virus were found to belong to Type I. This suggests that in Wayne and Medina Counties, Ohio, the 1952 epidemic was due predominantly to a Type I strain.

\section{Isolation of poliomyelitis virus from blood speci- mens}

Virus was demonstrated in the blood of two contacts of paralytic cases, one aged 10 months,

TABLE II

Isolation of Type I poliomyelitis virus from throat and/or rectal swabs from 91 contacts of poliomyelitis cases

\begin{tabular}{lccc}
\hline & & \multicolumn{2}{c}{$\begin{array}{c}\text { Type I virus isolation } \\
\text { by specimens }\end{array}$} \\
\cline { 3 - 4 } \multicolumn{1}{c}{ Specimens } & Contacts & Results & $\begin{array}{c}\text { Number } \\
\text { contacts }\end{array}$ \\
\cline { 3 - 4 } $\begin{array}{c}\text { Throat and rectal } \\
\text { swabs }\end{array}$ & 60 & $\mathrm{~T}^{*}+, \mathrm{R}^{*}+$ & 8 \\
& & $\mathrm{~T}+, \mathrm{R}-$ & 9 \\
& & $\mathrm{~T}-, \mathrm{R}+$ & 7 \\
Throat swabs only & 29 & $\mathrm{~T}-, \mathrm{R}-$ & 36 \\
& & $\mathrm{~T}+$ & 4 \\
Rectal swabs only & 2 & $\mathrm{~T}-$ & 25 \\
& & $\mathrm{R}+$ & 0 \\
& & $\mathrm{R}-$ & 2
\end{tabular}

* $\mathrm{T}+$ and $\mathrm{R}+$ or $\mathrm{T}$ - and $\mathrm{R}$ - indicate throat and rectal swabs positive or negative for Type I poliomyelitis virus, respectively. 
who 3 days later developed non-paralytic poliomyelitis; and one aged 17 years who remained asymptomatic. In addition viremia was detected in four children in one family who had no history of exposure to a known case. Three of these children had the "minor illness syndrome," and one was asymptomatic. A detailed report of these findings has appeared elsewhere (6).

\section{Isolation of poliomyelitis virus from throat and rectal swabs}

The results of the tests on the 91 contacts are shown in Table II in terms of the distribution of positive specimens, i.e., whether throat swabs or rectal swabs or both. The relatively large number with a positive throat swab and a negative rectal swab is perhaps a reflection of the method used; although rectal swabs are convenient and practical for survey purposes, they are less apt to yield virus than are stool specimens. However, with a rectal swab at least one knows from which child each specimen comes, and there is little chance for cross contamination within individual households.

The relationship of age and type of specimens tested to the number which were positive for virus is considered in Table III. No significant differences were noted in the age groups up to 15 years as to the frequency of virus isolation. There were more positive results when both throat and rectal swabs were tested, rather than either alone.

The type of exposure to a known case experienced by each individual, whether household or daily, was related to the number of persons who became infected; this is illustrated in Table IV,

TABLE III

Relation of age to the isolation of Type I poliomyelitis virus from 28 of 91 contacts of cases

\begin{tabular}{cccc}
\hline \hline & \multicolumn{3}{c}{ Specimens tested } \\
\cline { 2 - 4 } Age & $\mathrm{T}+\mathrm{R}^{*}$ & $\mathrm{~T}$ & $\mathrm{R}$ \\
\hline $0-4$ & $13 / 25 \dagger$ & & $0 / 1$ \\
$5-9$ & $6 / 16$ & $0 / 4$ & $0 / 1$ \\
$10-14$ & $5 / 16$ & $2 / 10$ & \\
$15-19$ & $0 / 3$ & $2 / 9$ & \\
$20+$ & & $0 / 6$ & \\
\hline Totals & $24 / 60$ & $4 / 29$ & $0 / 2$
\end{tabular}

* $\mathrm{T}$ and $\mathrm{R}=$ throat and rectal swabs.

$\dagger$ Numerator $=$ number positive for virus; denominator $=$ number tested.
TABLE IV

Relation of type of exposure to the readiness with which

Type I poliomyelitis virus was isolated from 24 of 60 contacts whose throat and rectal swabs were both tested

\begin{tabular}{ccc}
\hline \hline & \multicolumn{2}{c}{ Type of contact } \\
\cline { 2 - 3 } Age & Household & Daily \\
\hline $0-4$ & $11 / 13^{*}$ & $2 / 12$ \\
$5-9$ & $4 / 8$ & $2 / 8$ \\
$10-14$ & $5 / 12$ & $0 / 4$ \\
$15-19$ & $0 / 3$ & \\
\hline Totals & $20 / 36(56 \%)$ & $4 / 24(17 \%)$
\end{tabular}

* Numerator $=$ number positive $;$ denominator $=$ number tested.

in which are included only the 60 contacts from whom both throat and rectal swabs were available for testing. Of the household contacts, 20 of 36 were found to be infected, while for daily contacts the figures were 4 of 24 . The group which yielded the largest number of positive results was that composed of 0 to 4-year-old household contacts, in which 11 of 13 (in 10 households) were positive in contrast to 2 of 12 for the daily contacts in this age group. When data on all 91 contacts of cases were tabulated, the results turned out similarly 24 of 54 ( 44 per cent) household contacts were positive for virus, while 4 of 37 (11 per cent) of daily contacts were positive. When analyzed on an age basis it was found that $22 / 42$ ( 52 per cent) of those under 15 years were excreting virus in the household group, in contrast to $2 / 12$ (17 per cent) of those 15 years and over; 4 of 31 (13 per cent) daily contacts under 15 were positive, but none over 15 yielded virus.

\section{Antibody studies}

In order to evaluate the trends shown in these virus isolations from individuals of different ages and with different histories of contact, information as to the antibody status of the group under study was sought, for it seemed likely that in certain groups no virus was isolated because the individuals possessed antibodies and were, therefore, presumably immune. This question was analyzed by determining the poliomyelitis neutralizing antibody pattern for Types I, II, and III in those excreting virus and in those from whom no virus was isolated. Of the 28 individuals positive for Type I virus, 19 (68 per cent) had specific antibodies, while 9 were early enough in the course 
TABLE $\mathbf{v}$

Type I neutralising antibody pattern in 36 of 60 contacts whose throat and rectal swabs were negative for Type I poliomyelitis virus

\begin{tabular}{ccc}
\hline & \multicolumn{2}{c}{ Type of contact } \\
\cline { 2 - 3 } Age & Household & Daily \\
\hline $0-4$ & $2 / 2^{*}$ & $8 / 10$ \\
$5-9$ & $4 / 4$ & $6 / 6$ \\
$10-14$ & $7 / 7$ & $3 / 4$ \\
$15-19$ & $1 / 3$ & \\
\hline Totals & $14 / 16(87 \%)$ & $17 / 20(85 \%)$
\end{tabular}

* Numerator $=$ no. positive for antibodies; denominator = no. tested.

of infection to be still without a demonstrable Type I antibody response. Table $\mathrm{V}$ shows the pattern for Type I antibodies found in the 36 whose throat and rectal swabs had been tested and found negative for virus. The results indicate that a high percentage of both household and daily contacts, 87 per cent and 85 per cent, respectively, had Type I antibodies, either as a result of recent or remote infection.

A similar pattern was obtained when the entire group was analyzed as shown in Table VI, which summarizes the results of virus isolations from 28 of the total 91 contacts, and the antibody status of the 63 negative for virus. Of 42 household contacts under 15 years of age, 22 ( 52 per cent) were excreting virus, and all 20 of those negative for virus had Type I antibodies. For the age group 15 years and over, virus isolations were fewer, and only 58 per cent of those negative for virus had antibodies. The difference between household and daily contact groups as to virus isolation was great, but of the daily contacts, the per cent either excreting virus or possessing antibodies is similar to that for the household group : 90 per cent of those under 15 years, and 50 per cent of those 15 years and over. Again, whether or not the neutralizing antibodies present were the result of recent infection, i.e., in the current epidemic-or whether they represented infection in some previous year is not known; but an analysis of the antibody pattern to Types I, II, and III poliomyelitis virus suggests that in all probability a number of infections were acquired during the current epidemic (Table VII). Thus, a significant number of contacts in the age groups 0 to 4 and 5 to 9 had only Type I antibodies, or Type I plus II and/or III. The possibility exists that some of the Type II and III antibodies represent heterotypic responses to recent Type I infections (7). That the Type I antibodies could be heterotypic is unlikely, since no other virus types were isolated in any of the families or hospitalized cases.

\section{Relation of symptoms to the isolation of virus}

With the exception of three children in the contact group who subsequently developed nonparalytic poliomyelitis (and four others who were hospitalized secondary cases), illnesses in various individuals in the group were characterized by non-

TABLE VI

Summary of Type I poliomyelitis virus isolations from contacts, and Type I antibody status of those negative for virus

\begin{tabular}{clrr}
\hline \hline & & \multicolumn{2}{c}{ Type of contact } \\
\cline { 3 - 4 } Age & & Household & Daily \\
\hline \multirow{2}{*}{$0-14$} & Number & 42 & 31 \\
& Virus positive & 22 & 4 \\
& Virus negative & 20 & 27 \\
& Virus neg., antibody pos. & 20 & 24 \\
& Summary: & $22 / 42(52 \%)$ & $4 / 31(13 \%)$ \\
& Virus pos./No. tested & $42 / 42(100 \%)$ & $28 / 31(90 \%)$ \\
\hline & Virus or antibody pos./No. tested & 12 & 6 \\
& Number & 2 & 0 \\
& Virus positive & 10 & 6 \\
& Virus negative & 5 & 3 \\
& Virus neg., antibody pos. & $2 / 12(17 \%)$ & $0 / 6$ \\
& Summary: & $7 / 12(58 \%)$ & $3 / 6(50 \%)$ \\
\hline & Virus pos./No. tested & $24 / 54(44 \%)$ & $4 / 37(11 \%)$ \\
& Virus or antibody pos./No. tested & $49 / 54(91 \%)$ & $31 / 37(84 \%)$ \\
\hline
\end{tabular}


TABLE VII

Type I, II, and III poliomyelitis antibody patterns of 63 contacts negative for poliomyelitis virus

\begin{tabular}{|c|c|c|c|c|c|c|}
\hline Contact & Age & $\begin{array}{c}\text { Total } \\
\text { number }\end{array}$ & $\begin{array}{c}\text { Type I } \\
\text { only } \\
\text { (homotypic)* }\end{array}$ & $\begin{array}{c}\text { Antibodies } \\
\text { against Type } \\
\text { I+II +/or III } \\
\text { (homo- and } \\
\text { heterotypic) }\end{array}$ & $\begin{array}{l}\text { Type II + or } \\
\text { III only } \\
\text { (heterotypic) }\end{array}$ & $\begin{array}{l}\text { No anti- } \\
\text { bodies to } \\
\text { any type }\end{array}$ \\
\hline Household & $\begin{array}{l}0-4 \\
5-9 \\
10-14 \\
15+\end{array}$ & $\begin{array}{r}2 \\
6 \\
12 \\
10\end{array}$ & $\begin{array}{l}2 \\
1\end{array}$ & $\begin{array}{r}5 \\
12 \\
4\end{array}$ & 5 & 1 \\
\hline Daily & $\begin{array}{c}0-4 \\
5-9 \\
10-14 \\
15+\end{array}$ & $\begin{array}{r}11 \\
9 \\
7 \\
6\end{array}$ & $\begin{array}{l}6 \\
5 \\
1\end{array}$ & $\begin{array}{l}3 \\
3 \\
4 \\
2\end{array}$ & $\begin{array}{l}1 \\
3 \\
1\end{array}$ & $\begin{array}{l}2 \\
2\end{array}$ \\
\hline
\end{tabular}

* "Homotypic" refers to the Type I epidemic strain.

specific symptoms usually considered representative of the minor illness or abortive form of poliomyelitis which cannot be diagnosed clinically. These were slight fever, anorexia, sore throat, and headache, usually lasting not more than 24 to 48 hours; a few had more vague symptoms, such as a "cold," constipation, irritability, etc. The analysis of the relationship between the presence or absence of symptoms and the isolation of virus (Table VIII) showed that among the 91 household or daily contacts, 14 of 26 (54 per cent) of individuals with symptoms either during the three weeks prior to the collection of specimens, or at the time specimens were collected, were positive for virus; 11 of these had symptoms typical of the minor illness, and three had "colds." Of those asymptomatic during the same periods, 14 of 65 (23 per cent) yielded Type I poliomyelitis virus; presumably then, these 14 individuals were examples of inapparent infections. The percentage of virus isolation was higher in those with symptoms of the minor illness, especially in the younger children. The question as to how many failures to isolate virus were due to the fact that the individuals possessed antibodies and could, therefore, be considered immune, was investigated. When such antibody positive ("immune") individuals who were virus negative were eliminated from the analysis, then the score 14 of 17 ( 82 per cent) of those with symptoms were positive for virus, while 14 of 26 ( 54 per cent) of those who remained asymptomatic were infected, as demonstrated by the isolation of virus. The difference is not statistically significant. The difference between the symptomatic and asymptomatic group as to ease of virus isolation also disappears if all those negative for virus but positive for antibodies are assumed to be examples of inapparent infection during the current epidemic.

\section{Clinical manifestations-Ratio of inapparent to apparent infection among contacts}

The data were next analyzed from the point of view of clinical manifestations or their absence. In this analysis, the index cases were eliminated and only their household contacts (plus four additional family contacts who were secondary hospitalized cases) were included; the stool of two of these latter had been tested and found positive for Type I poliomyelitis virus.

Table IX indicates the various responses of these 58 individuals. The incidence of infection was high indeed, for of 31 "susceptibles," 28 be-

TABLE VIII

The presence of symptoms as compared with the isolation of Type I poliomyelitis virus from 91 close contacts

\begin{tabular}{lccccc}
\hline \hline & \multicolumn{2}{c}{ Symptoms present } & & \multicolumn{2}{c}{ Symptoms absent } \\
\cline { 2 - 3 } \cline { 6 - 6 } Age & \multicolumn{2}{c}{ Type of contact } & & \multicolumn{2}{c}{ Type of contact } \\
\cline { 2 - 3 } \cline { 6 - 6 } & Household & Daily & & Household & Daily \\
\hline $0-4$ & $6 / 6^{*}$ & $2 / 4$ & & $5 / 7$ & $0 / 9$ \\
$5-9$ & $3 / 3$ & $1 / 2$ & & $1 / 7$ & $1 / 9$ \\
$10-14$ & $1 / 4$ & $0 / 2$ & & $6 / 15$ & $0 / 5$ \\
$15+$ & $1 / 3$ & $0 / 2$ & & $1 / 9$ & $0 / 4$ \\
\hline Totals & $11 / 16$ & $3 / 10$ & & $13 / 38$ & $1 / 27$ \\
\cline { 2 - 3 } & $14 / 26(54 \%)$ & & \multicolumn{2}{c}{$14 / 65(23 \%)$} \\
\hline
\end{tabular}

Total positive if

"immune" (i.e.,

antibody pos.) $14 / 17(82 \%)$

eliminated from

virus neg. group

$14 / 26(54 \%)$

* Numerator $=$ number of individuals positive for Type I virus; denominator $=$ number tested. 
Clinical responses of familial associates of poliomyelitis cases

\begin{tabular}{|c|c|c|c|c|c|c|c|}
\hline \multirow[b]{3}{*}{ Age } & \multirow[b]{3}{*}{$\begin{array}{c}\text { Total } \\
\text { number }\end{array}$} & \multirow{2}{*}{\multicolumn{2}{|c|}{ "Susceptibles"* }} & \multicolumn{4}{|c|}{$\begin{array}{l}\text { Clinical manifestations } \\
28 \text { infected contacts }\end{array}$} \\
\hline & & & & \multirow[b]{2}{*}{$\begin{array}{c}\text { Inapparent } \\
\text { infection }\end{array}$} & \multicolumn{2}{|c|}{ Number with: } & \multirow[b]{2}{*}{ Paralytic } \\
\hline & & Number & $\begin{array}{l}\text { Per cent } \\
\text { infected }\end{array}$ & & Abortive & $\begin{array}{c}\text { Non- } \\
\text { paralytic }\end{array}$ & \\
\hline $\begin{array}{c}0-4 \\
5-9 \\
10-14 \\
15+\end{array}$ & $\begin{array}{l}13 \\
14 \\
19 \\
12\end{array}$ & $\begin{array}{r}11 \\
8 \\
7 \\
7\end{array}$ & $\begin{array}{r}100 \\
100 \\
100 \\
29\end{array}$ & $\begin{array}{l}5 \\
1 \\
6 \\
2\end{array}$ & $\begin{array}{l}3 \\
3 \\
1 \\
0\end{array}$ & $\begin{array}{l}3 \\
2 \\
0 \\
0\end{array}$ & $\begin{array}{l}0 \\
2 \\
0 \\
0\end{array}$ \\
\hline Totals & 58 & 31 & 90 & \multicolumn{2}{|c|}{21} & \multicolumn{2}{|c|}{7} \\
\hline
\end{tabular}

* "Susceptibles" as used here include 1) all contacts from whom virus was isolated; 2) two frank cases not tested for virus; 3 ) contacts negative for virus and negative for Type I antibodies.

came infected. All of the 7 frank cases were in children under 10 years of age, but the numbers are too few to draw conclusions about the clinical form of disease in relation to age. However, it is possible to compare the ratio of inapparent and abortive infections to frank clinical cases. Of the 28 infected persons, 21 had either inapparent or abortive poliomyelitis, while 7 had the frank clinical disease, either paralytic or nonparalytic, a ratio of $3: 1$.

\section{DISCUSSION}

The incidence of infection among contacts of poliomyelitis cases has been studied by many investigators, and there is ample evidence that both asymptomatic infections and minor illnesses are common in familial and other associates of cases. Only recently, however, since the introduction of tissue culture methods, has it been feasible in large studies to correlate the isolation of virus with the presence or absence of antibodies to the infecting type of poliomyelitis virus. In results recently published by Brown, Rabson, and Schieble (8) in which the excretion of virus and development of antibodies was studied in 55 family contacts who had received gamma globulin, the results were remarkably similar to those of the present investigation. The above authors, conducting their study in Michigan in the summer of 1953, found that 23 of the 55 household contacts were excreting virus; that 27 ( 85 per cent) of those negative for virus already had antibodies to the family strain. In our study conducted in Ohio during the summer of 1952, 24 of 54 familial associates were found to be positive for the family type of virus, and 25 ( 83 per cent) of those from whom no virus was isolated already had antibodies. Thus in both studies, 91 per cent of family contacts were either excreting virus, or possessed antibodies to the family type. Similar high infection rates among familial associates have been reported earlier by Brown and Ainslie (9) and, more recently, by Bodian and Paffenbarger (10).

In considering the ease of virus isolation from symptomatic as compared to asymptomatic contacts, as might be expected, a higher percentage of positives was obtained in those with symptoms (54 per cent) in contrast to the asymptomatic group (23 per cent). The difference is probably explained by the fact that in the asymptomatic group, many possessed Type I antibodies and were therefore "immune" because of previous exposure, and others, who had been infected earlier in the current epidemic, were actually examples of inapparent infection.

As to the clinical responses of family contacts of cases, it is apparent from Table IX that the $3: 1$ ratio of inapparent to apparent infections is considerably different from the 100:1 or greater ratio usually given for the general population. Even if the 25 family contacts negative for virus but possessing Type I antibodies (Table VI) are all considered to be examples of inapparent infection during the current epidemic, the ratio is still only $46: 7$, or approximately $7: 1$. The results suggest that infected families in which a frank case has occurred form a special, highly exposed group, with a relatively high risk of clinical disease. A number of factors including virus dosage may be responsible for this situation. On the experimental side, for instance, it has been observed 
by Sabin and Winsser (11) that small doses of virus repeatedly fed to cynomolgus monkeys produce predominantly inapparent infection; in contrast, animals fed large doses of virus are prone to develop paralytic poliomyelitis in a high per cent of instances. By analogy, family associates of a case might be considered to be a special group, probably exposed to large amounts of virus, and hence having a relatively high attack rate of paralytic and nonparalytic infections. In contrast, in a normal population which lives through an epidemic without known exposure to a case, a high incidence of inapparent infection is demonstrable. Such a group was described by Melnick and Ledinko (12) who measured the conversion rate from negative to positive antibody status in 250 normal children who lived in Winston-Salem, N. C., during an epidemic there in 1948. The ratio of inapparent infections in the group studied to reported cases in the community was calculated to range from $175: 1$ in infants under 1 year to $62: 1$ and $95: 1$ for children 5 to 9 and 10 to 14 years of age, respectively. The high inapparent infection rate in such individuals with no known exposure might be correlated with the size of the infecting dose: as with monkeys fed small doses of virus, minimal exposure produced inapparent infection and immunity. Thus it has been said (and there is increasing evidence on this point [13]) that to some extent paralytic poliomyelitis "breeds" paralytic poliomyelitis, while asymptomatic infections in the population at large breed asymptomatic infections.

In any event, the results of the present study are in line with others $(8-10)$ in pointing to an extraordinarily high infection rate among susceptible individuals closely exposed to a case. It may be assumed on the basis of the evidence presented that by the time a case of poliomyelitis occurs in a family, virtually all other members of the family who are not immune by virtue of previous exposure and infection have become infected, whether or not they develop symptoms. Thus, poliomyelitis may be said to rank with measles as to degree of contagiousness in a family setting.

\section{SUMMARY}

1. The incidence of infection among 91 contacts of poliomyelitis cases has been studied dur- ing an epidemic due to Type I. Virus isolations as a measure of infection have been correlated with immune status, i.e., the presence or absence of antibodies.

2. The incidence of infection among household and daily contacts of diagnosed cases was high. If only antibody negative (and therefore presumably susceptible) contacts are considered, the infection rates for those under 15 years of age were 100 per cent for household contacts, and 87 per cent for daily contacts.

3. Type I poliomyelitis virus was isolated with greater frequency from those with symptoms than from those who remained asymptomatic. However, many of the asymptomatic group were demonstrated already to possess antibodies to the family type of virus; when these were eliminated, there was no significant difference in the ease of virus isolation from individuals with symptoms as compared to those who remained asymptomatic.

4. In analyzing the clinical response to poliomyelitis virus infection among family associates of cases, it was found that the ratio of inapparent to apparent infection was approximately $3: 1$ (and not higher than $7: 1$ ). It is suggested that the high incidence of apparent infections in the group studied (compared to the ratio for the general population) might be related, in part at least, to factors of exposure and dosage: in a family in which a frank case occurs, exposure is of a high degree, the dosage of virus is presumably large, and the incidence of paralytic and nonparalytic infections is correspondingly high.

5. On the basis of virus isolations and serological evidence, poliomyelitis infection may be said to be as contagious as measles among susceptible individuals in a family setting.

\section{REFERENCES}

1. Kleinschmidt, E. E., Abbott, M., and Kauffman, E. I., The Health Department and poliomyelitis. Administrative factors in the 1952 outbreak in Wayne and Medina Counties, Ohio. U. S. Pub. Health Rep., 1952, 67, 1109.

2. Ledinko, N., Riordan, J. T., and Melnick, J. L., Multiplication of poliomyelitis viruses in tissue cultures of monkey testes. I. Growth curves of Type I (Brunhilde) and Type 2 (Lansing) strains and description of a quantitative neutralization test. Am. J. Hyg., 1952, 55, 323.

3. Morann, G. L., and Melnick, J. L., Poliomyelitis virus in tissue culture. VI. Use of kidney epithelium 
grown on glass. Proc. Soc. Exper. Biol. \& Med., 1953, 84, 558.

4. Melnick, J. L., Ramos-Alvarez, M., Black, F. L., Girardi, A. J., and Nagaki, D., Poliomyelitis viruses in tissue culture. VII. Experiences with viral and serological diagnostic procedures. Yale J. Biol. \& Med., 1954, 26, 465.

5. Riordan, J. T., Ledinko, N., and Melnick, J. L., Multiplication of poliomyelitis viruses in tissue cultures of monkey testes. II. Direct isolation and typing of strains from human stools and spinal cords in roller tubes. Am. J. Hyg., 1952, 55, 339.

6. Horstmann, D. M., McCollum, R. W., and Mascola, A. D., Viremia in human poliomyelitis. J. Exper. Med., 1954, 99, 355.

7. Sabin, A. B., Transitory appearance of Type 2 neutralizing antibody in patients infected with Type 1 poliomyelitis virus. J. Exper. Med., 1952, 96, 99.

8. Brown, G. C., Rabson, A. S., and Schieble, J. H., The effect of gamma globulin on subclinical infection in familial associates of poliomyelitis cases.
II. Serological studies and virus isolations from pharyngeal secretions. J. Immunol., 1955, 74, 71.

9. Brown, G. C., and Ainslie, J. D., Relationship between serum antibodies and subclinical infections with poliomyelitis virus. J. Exper. Med., 1951, 93, 197.

10. Bodian, D., and Paffenbarger, R. S., Jr., Poliomyelitis infection in households. Frequency of viremia and specific antibody response. Am. J. Hyg., 1954, $60,83$.

11. Sabin, A. B., and Winsser, J., Immunogenic effect of repeated ingestion of minute amounts of poliomyelitis virus. Federation Proc., 1953, 12, 456.

12. Melnick, J. L., and Ledinko, N., Development of neutralizing antibodies against the three types of poliomyelitis virus during an epidemic period. The ratio of inapparent infection to clinical poliomyelitis. Am. J. Hyg., 1953, 58, 207.

13. Siegel, M., and Greenberg, M., Risk of paralytic and nonparalytic forms of poliomyelitis to household contacts. J. A. M. A., 1954, 155, 429. 